\title{
An association study of $H F E$ gene mutation with idiopathic male infertility in the Chinese Han population
}

\author{
Xiao-Ying Yu ${ }^{1, *}$, Bin-Bin Wang ${ }^{2,3, *}$, Zhong-Cheng Xin ${ }^{4}$, Tao Liu ${ }^{1}, \mathrm{Ke} \mathrm{Ma}^{1}$, Jian Jiang ${ }^{1}, \mathrm{Xiang}_{\text {Fang }}{ }^{1}$, Li-Hua Yu ${ }^{1}$, \\ Yi-Feng Peng ${ }^{1}$ and $\mathrm{Xu} \mathrm{Ma}{ }^{2,3,5}$
}

Mutations in the haemochromatosis gene (HFE) influence iron status in the general population of Northern Europe, and excess iron is associated with the impairment of spermatogenesis. The aim of this study is to investigate the association between three mutations (C282Y, H63D and S65C) in the HFE gene with idiopathic male infertility in the Chinese Han population. Two groups of Chinese men were recruited: 444 infertile men (including 169 with idiopathic azoospermia) and 423 controls with proven fertility. The $H F E$ gene was detected using polymerase chain reaction-restriction fragment length polymorphism (PCR-RFLP) technique. The experimental results demonstrated that no $\mathrm{C282Y}$ or $\mathrm{S} 65 \mathrm{C}$ mutations were detected. Idiopathic male infertility was not significantly associated with heterozygous H63D mutation (odds ratio $=0.801,95 \%$ confidence interval $=0.452-1.421, \chi^{2}=0.577, P=0.448$ ). The H63D mutation frequency did not correlate significantly with the serum luteinizing hormone (LH), follicle-stimulating hormone (FSH) and testosterone (T) levels in infertile men ( $P=0.896, P=0.404$ and $P=0.05$, respectively). Our data suggest that the HFE H63D mutation is not associated with idiopathic male reproductive dysfunction.

Asian Journal of Andrology (2012) 14, 599-603; doi:10.1038/aja.2012.1; published online 16 April 2012

Keywords: gene mutation; gonadotropic hormone; HFE; male infertility

\section{INTRODUCTION}

Idiopathic azoospermia and idiopathic oligospermia are two common reasons for male infertility. Although the potential causes are not yet clearly understood, interactions between genetic and environmental factors have been suggested to be implicated in the conditions of poor sperm function and infertility. ${ }^{1-4}$ As a common autosomal recessive genetic disorder, hereditary haemochromatosis $(\mathrm{HH})$, is characterized by iron overload in the parenchymal tissue of many organs, including the pituitary, liver, pancreas, heart, endocrine organs and joints, due to increased iron absorption in the gastrointestinal tract. ${ }^{5,6}$ The clinical consequences of iron accumulation in these organs include hypogonadism, hepatocellular carcinoma, cirrhosis of the liver, heart failure, idiopathic cardiomyopathy diabetes and arthritis, and if untreated, some cases may be fatal. ${ }^{5}$ In 1976, HH was linked to particular human leukocyte antigen (HLA) alleles. However, it was another 20 years before two mutations in the haemochromatosis gene (HFE) gene on chromosome $6 \mathrm{p} 21.3$ were confirmed to be linked to the majority of the disease cases. ${ }^{7,8}$ The protein product of the HFE gene has a structure similar to that of MHC class I molecules. Three HFE mutations have now been identified: C282Y, H63D and S65C. ${ }^{9-11}$ C282Y, a G-to-A transition at nucleotide 845 (G845A) in exon 4 of the HFE gene, results in a cysteine-to-tyrosine substitution at position 282 . H63D is a C-toG transition at nucleotide $187(\mathrm{C} 187 \mathrm{G})$ in exon 2, causing a histidineto-aspartic acid substitution at amino acid 63 . The third mutation,
S65C, involves the substitution of adenine with thymidine at nucleotide 193 in exon 2 and leads to a serine-to-cysteine substitution at position 6. Feder et al. ${ }^{12}$ reported that wild-type HLA-H binds to $\beta 2$-microglobulin, and the C282Y HFE mutation completely abrogated this interaction and disrupted intracellular protein trafficking. This report describes the first functional significance of the C282Y mutation and indicates that an abnormality in protein trafficking and/or cell-surface expression of HLA-H leads to HH disease. It has been reported ${ }^{13}$ that $\mathrm{H} 63 \mathrm{D}$ mutations predominantly influence the binding of HFE to the transferrin receptor, which plays a role in cellular iron uptake. According to animal model studies, ${ }^{14,15}$ excess iron induces oxidative stress and the impairment of spermatogenesis.

\section{MATERIALS AND METHODS}

\section{Study populations}

This study was approved by the Ethics Committee of Wannan Medical College. All of the subjects were randomly selected from the Chinese Han population at the Institute of Reproductive Medicine, Yijishan Hospital, Anhui, China. A total of 867 unrelated Chinese men were recruited from July 2008 to April 2011, including 444 patients with idiopathic male infertility and 423 fertile volunteers. The criterion for inclusion in the case group was infertility, as judged by abnormal semen parameters on at least two separate analyses, with sperm parameters below the cutoff levels defined by the World Health

${ }^{1}$ Institute of Reproductive Medicine, Yijishan Hospital, Wannan Medical College, Wuhu 241001, China; ${ }^{2}$ National Research Institute for Family Planning, Beijing 100081, China; ${ }^{3}$ Peking Union Medical College, Beijing 100081, China; ${ }^{4}$ Andrology Center, Peking University First Hospital, Beijing 100034, China and ${ }^{5}$ World Health Organization Collaborating Centre for Research in Human Reproduction, Beijing 100081, China

*These authors contributed equally to the work.

Correspondence: Professor YF Peng (yifengpeng@yahoo.cn) or Professor X Ma (Nicgr@263.net)

Received: 30 October 2011; Revised: 12 December 2011; Accepted: 2 January 2012; Published online: 16 April 2012 
Table 1 Clinical characteristics of the 444 infertile patients

\begin{tabular}{|c|c|c|c|c|}
\hline & \multirow{2}{*}{$\begin{array}{c}\text { Azoospermia } \\
\mathrm{n}=169\end{array}$} & \multicolumn{2}{|c|}{ Oligoasthenospermia } & \multirow{2}{*}{$\begin{array}{l}\text { Asthenospermia } \\
\begin{array}{c}\geqslant 20 \times 10^{6} \mathrm{ml}^{-1} \\
\mathrm{n}=64\end{array}\end{array}$} \\
\hline & & $\mathrm{n}=107$ & $\mathrm{n}=104$ & \\
\hline Infertility duration (year) & $3.09 \pm 2.99$ & $2.59 \pm 2.69$ & $2.75 \pm 2.85$ & $2.48 \pm 2.03$ \\
\hline \multicolumn{5}{|l|}{ Smoking } \\
\hline Yes & $90(53.25 \%)$ & $50(46.73 \%)$ & $53(50.96 \%)$ & 27 (42.19\%) \\
\hline Yes & $29(17.16 \%)$ & $25(23.36 \%)$ & $19(18.27 \%)$ & $13(20.31 \%)$ \\
\hline No & $140(82.84 \%)$ & $82(76.64 \%)$ & $85(81.73 \%)$ & $51(79.69 \%)$ \\
\hline \multicolumn{5}{|l|}{ High temperature } \\
\hline Yes & $25(14.79 \%)$ & $9(8.41 \%)$ & $11(10.58 \%)$ & $3(4.69 \%)$ \\
\hline No & $144(85.21 \%)$ & $98(91.59 \%)$ & $93(89.42 \%)$ & $61(95.31 \%)$ \\
\hline \multicolumn{5}{|l|}{ Serum hormones } \\
\hline$T\left(n g m l^{-1}\right)$ & $4.43 \pm 2.71$ & $4.60 \pm 2.83$ & $4.72 \pm 2.29$ & $4.93 \pm 1.57$ \\
\hline \multicolumn{5}{|l|}{ Semen parameters } \\
\hline Ejaculate volume (ml) & $2.21 \pm 0.76$ & $2.15 \pm 0.83$ & $2.43 \pm 0.94$ & $2.25 \pm 0.96$ \\
\hline Sperm density $\left(\times 10^{6} \mathrm{ml}^{-1}\right)$ & - & $2.40 \pm 1.32$ & $10.27 \pm 4.13$ & $42.93 \pm 33.15$ \\
\hline Motility (\% motile) & - & $17.56 \pm 19.08$ & $26.57 \pm 16.79$ & $18.37 \pm 14.16$ \\
\hline
\end{tabular}

Abbreviations: $E_{2}$, estradiol; FSH, follicle-stimulating hormone; LH, luteinizing hormone; PRL, prolactin; T, testosterone.

Values are expressed as mean \pm s.d.

Organization (in 1999). Exclusion criteria included Y chromosome microdeletions or karyotype abnormalities, genital trauma or testicular torsion, a testicular volume of less than $10 \mathrm{ml}$, cryptorchidism, varicocele, and the use of immunosuppressants or cytotoxic drugs. All of the control individuals had fathered at least one child and had normal semen parameters. Semen specimens were collected by masturbation into a sterile plastic container after at least 3 days of sexual abstinence. All the men voluntarily signed the informed consent for molecular analysis of their blood samples. The clinical characteristics for the 444 patients with idiopathic male infertility are presented in Table 1.

\section{Genotyping}

The infertile men were grouped according to their sperm count as having azoospermia or oligoasthenospermia $\left(<5 \times 10^{6}\right.$ and $\geqslant 5 \times 10^{6}$ sperm $\mathrm{ml}^{-1}$, respectively). In our study, there were 169 patients with non-obstructive azoospermia and 211 subjects with oligoasthenospermia. Sixty-four of these patients had asthenospermia (sperm count $\geqslant 20 \times 10^{6} \mathrm{ml}^{-1}$ but progressive sperm motility $\left.<50 \%\right)$. The serum follicle-stimulating hormone (FSH), luteinizing hormone (LH), prolactin, estradiol $\left(\mathrm{E}_{2}\right)$ and testosterone $(\mathrm{T})$ levels were assessed by magnetic-separation ELISA (Clontech; Beijing Bio-Ekon Biotechnology
Co., Ltd, Beijing, China). The results were considered within the normal range: FSH, 1.67-11.98 $\mathrm{mIU} \mathrm{ml}^{-1}$; $\mathrm{LH}, 3.0-12.0 \mathrm{mIU} \mathrm{ml}^{-1}$; prolactin, 5.0-17.0 $\mathrm{ng} \mathrm{ml}^{-1} ; \mathrm{E}_{2},<41.42 \mathrm{pg} \mathrm{ml}^{-1}$; and T, 2.41-11.41 ng $\mathrm{ml}^{-1}$. Genomic DNA was extracted from the peripheral blood using a TIANamp Blood DNA Kit (offered by Tiangen Biotech Co., Ltd, Beijing, China). The analysis of HFE gene mutations was performed using PCR-RFLP analysis with the primers described by Feder et al. ${ }^{8}$ The thermocycling conditions consisted of an initial denaturation of 5 min at $94^{\circ} \mathrm{C}, 30$ cycles of $1 \mathrm{~min}$ at $94^{\circ} \mathrm{C}, 1 \mathrm{~min}$ at $63.1^{\circ} \mathrm{C}$, and $1 \mathrm{~min}$ at $72{ }^{\circ} \mathrm{C}$, and a final extension of $10 \mathrm{~min}$ at $72^{\circ} \mathrm{C}$. The PCR products were then digested at $37^{\circ} \mathrm{C}$ for $16 \mathrm{~h}$ with $5 \mathrm{U}$ of Mbo I, $2.5 \mathrm{U}$ of Hinf I or $2.5 \mathrm{U}$ of Rsa I in a $10-\mu \mathrm{l}$ reaction mixture (New England Biolabs Co., Ltd., Beijing, China; Table 2). Finally, the restriction fragments were separated by electrophoresis on $4 \%$ agarose gels, and the results were visualised under UV illumination (JS-680B; Shanghai Peiqing Science \& Technology. Co., Ltd, Shanghai, China).

\section{Meta-analysis}

Two online electronic databases (PubMed and HighWire) were searched, and the last search update was November 2011, with the keywords of 'HFE mutation', 'HFE polymorphism', 'infertility', 'azoospermia', 'oligozoospermia' and 'male infertility'. The search

Table 2 Genotyping assays to analyze the HFE mutation

\begin{tabular}{|c|c|c|c|c|c|}
\hline Mutation & Base change & Primer & PCR product (bp) & $\begin{array}{l}\text { Restriction } \\
\text { enzyme }\end{array}$ & Restriction products \\
\hline H63D (rs 1799945) & $C>G$ & $\begin{array}{l}\text { 5'-ACATGGTTAAGGCCTGTTGC-3' (forward) } \\
\text { 5'-GCCACATCTGGCTTGAAATT-3' (reverse) }\end{array}$ & 208 & Mbol & $\begin{array}{l}\text { C allele: } 138+70 \text { bp } \\
\text { G allele: } 208 \text { bp }\end{array}$ \\
\hline S65C (rs 180073) & $A>T$ & $\begin{array}{l}\text { 5'-ACATGGTTAAGGCCTGTTGC-3' (forward) } \\
\text { 5'-GCCACATCTGGCTTGAAATT-3' (reverse) }\end{array}$ & 208 & Hinf I & $\begin{array}{l}\text { A allele: } 147+61 \text { bp } \\
\text { T allele: } 208 \text { bp }\end{array}$ \\
\hline C282Y (rs 1800562) & $G>A$ & $\begin{array}{l}\text { 5'-TGGCAAGGGTAAACAGATCC-3' (forward) } \\
\text { 5'-CTCAGGCACTCCT CTCAACC-3' (reverse) }\end{array}$ & 387 & Rsa I & $\begin{array}{l}\text { A allele: } 247+140 \text { bp } \\
\text { G allele: } 387 \text { bp }\end{array}$ \\
\hline
\end{tabular}


Table 3 The frequency of HFE genotype in infertile and control men from published studies

\begin{tabular}{|c|c|c|c|c|c|c|c|c|c|}
\hline \multirow{3}{*}{$\frac{\text { Population }}{\text { Slovenia }}$} & \multirow{2}{*}{$\begin{array}{r}\text { Reference } \\
\text { Peterlin et al. }{ }^{24}\end{array}$} & Group & \multicolumn{3}{|c|}{$H 63 D$} & \multicolumn{3}{|c|}{$\mathrm{C} 282 \mathrm{Y}$} & \multirow[t]{2}{*}{$S 65 C$} \\
\hline & & Cases & wt/wt & H63D/wt & $\mathrm{H} 63 \mathrm{D} / \mathrm{H} 63 \mathrm{D}$ & wt/wt & $\mathrm{C} 282 \mathrm{Y} / \mathrm{wt}$ & C282Y/C282Y & \\
\hline & & 262 & $192(73.28 \%)$ & $64(24.43 \%)$ & $5(1.91 \%)$ & $240(91.60 \%)$ & $22(8.40 \%)$ & 0 & ND \\
\hline & & Controls & & & & & & & \\
\hline & & 200 & $150(75.00 \%)$ & $44(22.00 \%)$ & $6(3.00 \%)$ & $187(93.50 \%)$ & $13(6.50 \%)$ & 0 & ND \\
\hline \multirow[t]{4}{*}{ Turkey } & Gunel-Ozcan et al. ${ }^{25}$ & Cases & & & & & & & \\
\hline & & 148 & $114(77.03 \%)$ & $34(22.97 \%)$ & 0 & ND & ND & ND & ND \\
\hline & & Controls & & & & & & & \\
\hline & & 0 & & & & & & & \\
\hline \multirow[t]{4}{*}{ Croatia } & Buretić-Tomljanović & Cases & & & & & & & \\
\hline & et al. ${ }^{17}$ & 127 & $94(74.02 \%)$ & $30(23.62 \%)$ & $3(2.36 \%)$ & $122(96.06 \%)$ & $5(3.94 \%)$ & 0 & ND \\
\hline & & Controls & & & & & & & \\
\hline & & 188 & $134(71.28 \%)$ & 50 (26.60\%) & $4(2.12 \%)$ & $178(94.68 \%)$ & $10(5.32 \%)$ & 0 & ND \\
\hline \multirow[t]{4}{*}{ China } & This study & Cases & & & & & & & \\
\hline & & 444 & $421(94.82 \%)$ & $23(5.18 \%)$ & 0 & 444 (100.00\%) & 0 & 0 & NM \\
\hline & & Controls & & & & & & & \\
\hline & & 423 & 396 (93.62\%) & $27(6.38 \%)$ & 0 & 423 (100.00\%) & 0 & 0 & NM \\
\hline
\end{tabular}

Abbreviations: ND, not determined; NM, no mutation.

was limited to English-language papers. Studies included in our metaanalysis were required to meet the following criteria: (i) they must have used a case-control design; and (ii) they must have provided sufficient data for determination of an odds ratio (OR) with a $95 \%$ confidence interval (CI). The major reason for the exclusion of studies was the lack of a control population. Two investigators independently extracted data according to the inclusion and exclusion criteria and reached a consensus on all the items. The following data were collected from the studies: the first author, the year of publication, the study design (population- or hospital-based controls), ethnicity of the study subjects, the genotyping methods, the main characteristics of the cases and controls, and the numbers of genotyped cases and controls. Different ethnic descents were categorised as Caucasian and Asian. Two studies were included based on the search criteria for male infertility susceptibility related to the HFE mutations. The study characteristics are summarized in Table 3.

\section{Statistical analyses}

All the statistical analyses were performed using SPSS statistical software (version 13.0; SPSS, Inc., Chicago, IL, USA).The allele and genotype frequencies were calculated by gene counting. The Hardy-Weinberg equilibrium was tested using the Chi-squared test. The meta-analysis was performed by $\mathrm{R}$ language programming (http://www.r-project.org/). The clinical data were expressed as the mean \pm s.d. (age, infertility duration, serum hormones and semen parameters). The frequency of HFE H63D was analysed using the Chi-squared test or Fisher's exact test if one of the expected numbers was less than five. A two-tailed $P$ value $<0.05$ was considered statistically significant. Correlations between serum FSH, LH and T levels and the distribution of the HFE genotype frequencies were analysed using the non-parametric Mann-Whitney test.

\section{RESULTS}

A total of 867 samples (169 azoospermia, 211 oligoasthenospermia, 64 asthenospermia, and 423 controls from participants with proven fertility) were analysed for the presence of HFE H63D, S65C and C282Y mutations. The HFE genotype distribution was in Hardy-Weinberg equilibrium $(P=1.000)$. No $\mathrm{C} 282 \mathrm{Y}$ or S65C mutations were detected in our study. The H63D genotyping data are summarized in Table 4. In this study, the H63D HFE genotype distributions in infertile men (CC $94.8 \%$, GC 5.2\%, GG $0 \%)$ were not significantly different $(\mathrm{OR}=0.801$, $\left.95 \% \mathrm{CI}=0.452-1.421, \chi^{2}=0.577, P=0.448\right)$ from those in the fertile controls (CC 93.6\%, GC 6.4\%, GG 0\%). We further analysed the distribution of the H63D mutation frequencies in patients with azoospermia, oligozoospermia and asthenospermia, but still found no significant differences compared with the control group (Table 4). There was no statistically significant difference $(P=0.896 ; P=0.404 ; P=0.05)$ between the frequency of the H63D mutation and the serum LH, FSH or T levels in infertile men (Table 5). The meta-analysis showed that the H63D and $\mathrm{C} 282 \mathrm{Y}$ mutations were not significantly associated with male infertility risk $(\mathrm{H} 63 \mathrm{D} / \mathrm{H} 63 \mathrm{D}+\mathrm{H} 63 \mathrm{D} / \mathrm{wt}$ vs. wt/wt: $\mathrm{OR}=0.94,95 \% \mathrm{CI}=0.71-1.25$, $P=0.674 ; \quad \mathrm{C} 282 \mathrm{Y} / \mathrm{C} 282 \mathrm{Y}+\mathrm{C} 282 \mathrm{Y} / \mathrm{wt} \quad$ vs. $\quad \mathrm{wt} / \mathrm{wt}: \mathrm{OR}=1.11, \quad 95 \%$ $\mathrm{CI}=0.61-2.01, P=0.375$; Table 6 and Figures 1 and 2).

\section{DISCUSSION}

Gonadal insufficiency is believed to be caused by iron-induced damage to the testicular Leydig cells, which produce $\mathrm{T}$, or to the pituitary gonadotrophs that secrete $\mathrm{LH}$ and $\mathrm{FSH} .{ }^{16}$ In animal models, excessive

Table 4 The frequency of HFE genotypes and alleles in infertile patients and controls

\begin{tabular}{|c|c|c|c|c|c|c|}
\hline \multirow{2}{*}{$\frac{\text { Genotype }}{\text { H63D }}$} & \multirow{2}{*}{$\begin{array}{l}\text { Cases } \\
n=444\end{array}$} & \multirow{2}{*}{$\frac{\text { Azoospermia }}{n=169}$} & \multicolumn{2}{|c|}{ Oligoasthenospermia } & \multirow{2}{*}{$\begin{array}{l}\text { Asthenospermia } \\
\geqslant 20 \times 10^{6} \mathrm{ml}^{-1} n=64\end{array}$} & \multirow{2}{*}{$\begin{array}{c}\text { Controls } \\
n=423\end{array}$} \\
\hline & & & $<5 \times 10^{6} \mathrm{ml}^{-1} \mathrm{n}=107$ & $\geqslant 5 \times 10^{6} \mathrm{ml}^{-1} \mathrm{n}=104$ & & \\
\hline $\mathrm{CC}$ & $421(94.8 \%)$ & $159(94.08 \%)$ & $103(96.26 \%)$ & $96(92.31 \%)$ & $63(98.44 \%)$ & $396(93.6 \%)$ \\
\hline GC & $23(5.2 \%)$ & $10(5.91 \%)$ & $4(3.74 \%)$ & $8(7.69 \%)$ & $1(1.56 \%)$ & $27(6.4 \%)$ \\
\hline OR $(95 \% \mathrm{Cl})$ & $0.801(0.452-1.421)$ & $0.922(0.436-1.950)$ & $0.570(0.195-1.664)$ & $1.222(0.538-2.775)$ & $0.233(0.031-1.744)$ & \\
\hline$\chi^{2}$ & 0.577 & 0.045 & 1.085 & 0.231 & 2.384 & \\
\hline$P$ value (two-sided) & 0.448 & 0.833 & 0.298 & 0.631 & 0.123 & \\
\hline
\end{tabular}

Abbreviations: $\mathrm{Cl}$, confidence interval; OR, odds ratio. 
Table 5 Serum hormone levels according to the HFE H63D genotype in 444 men with idiopathic infertility

\begin{tabular}{lccccc}
\hline Serum hormone & \multicolumn{2}{c}{ H63D mean rank } & & $\begin{array}{c}\text { Mann-Whitney } \\
\text { U/ } \chi^{2} \text { value }\end{array}$ & P value \\
\cline { 2 - 3 } & CC & GC & & \\
\hline $\mathrm{LH}\left(\mathrm{mlU} \mathrm{ml}^{-1}\right)$ & 222.31 & 225.83 & & 4960.000 & 0.896 \\
$\mathrm{FSH}\left(\mathrm{mlU} \mathrm{ml}^{-1}\right)$ & 223.71 & 201.25 & & 4530.000 & 0.404 \\
$\mathrm{~T}\left(\mathrm{ng} \mathrm{ml} \mathrm{mln}^{-1}\right)$ & 225.35 & 172.54 & & 3841.000 & 0.05 \\
\hline
\end{tabular}

Abbreviations: FSH, follicle-stimulating hormone; LH, luteinizing hormone; T, testosterone.

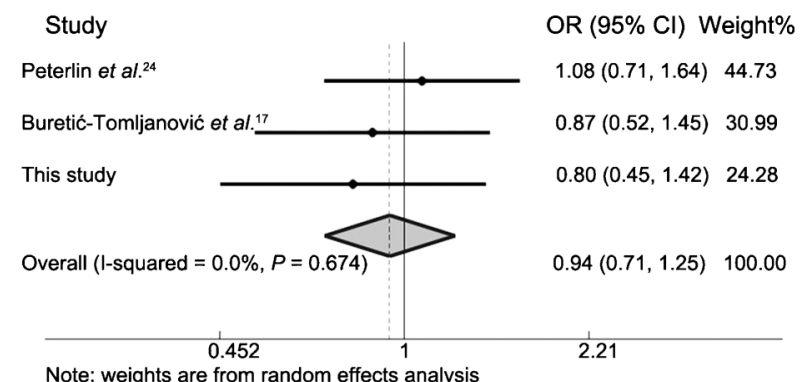

Figure 1 Results of individual and summary odds ratio estimates with $95 \% \mathrm{Cl}$ (the random-effect model): H63D mutation and infertile, comparing homozygous carriers of the mutation plus heterozygous carriers (H63D/H63D+H63D/wt) versus homozygous carriers of the wild type allele (wt/wt). The size of the square is proportional to the percent weight of each study, horizontal line represents the $95 \% \mathrm{Cl}$. Cl, confidence interval; OR, odds ratio.

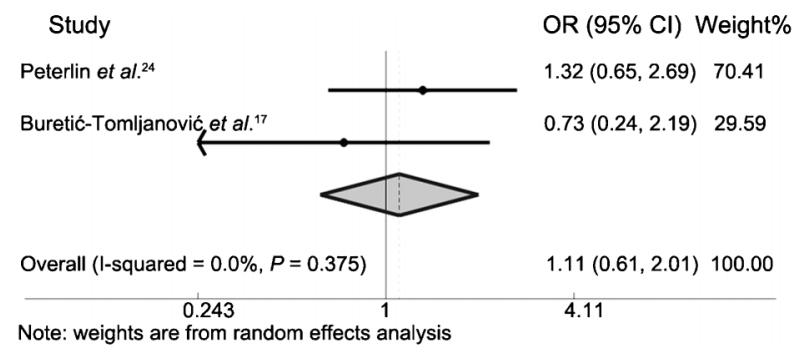

Figure 2 Results of individual and summary odds ratio estimates with $95 \% \mathrm{Cl}$ (the random-effect model): $\mathrm{C} 282 \mathrm{Y}$ mutation and infertile, comparing homozygous carriers of the mutation plus heterozygous carriers (C282Y/ $\mathrm{C} 282 \mathrm{Y}+\mathrm{C} 282 \mathrm{Y} / \mathrm{wt}$ ) versus homozygous carriers of the wild type allele (wt/wt). The size of the square is proportional to the percent weight of each study, horizontal line represents the $95 \% \mathrm{Cl}$. $\mathrm{Cl}$, confidence interval; OR, odds ratio.

iron impairs testicular function and spermatogenesis; moreover, reduced sperm production and small testes may be related to elevated iron concentrations. ${ }^{14,15}$ Disorders of testicular function comprise reproductive dysfunction (abnormalities in germ cell maturation) and/or endocrine dysfunction (abnormalities in the Leydig cells).
FSH and LH are gonadotropins that are secreted by pituitary gonadotropic cells: FSH stimulates Sertoli cell-supported spermatogenesis in the seminiferous tubules of the testis, and LH stimulates T production in the Leydig cells. ${ }^{17}$ Sertoli cells supply the structural support and optimal environment for spermatogenesis, and their number in the testis is a key feature affecting the number of mature sperm formed in the adult testis. ${ }^{18}$ Abnormal LH pulsatile secretion may be associated with male infertility and could disrupt the regulatory role of both the Sertoli and Leydig cells, resulting in abnormal spermatogenesis. ${ }^{19}$

To investigate the role of HFE in the regulation of iron homeostasis, Zhou et al. ${ }^{20}$ generated a knockout mouse model of HH by targeted disruption of the murine HFE gene. This study revealed that the HFE protein was involved in the regulation of iron homeostasis and that mutations in this gene were responsible for HH. The mouse model facilitated investigation into the pathogenesis of increased iron accumulation in $\mathrm{HH}$ and provided opportunities to evaluate therapeutic strategies for the prevention and correction of iron overload. HFE mutations interfere with hepcidin induction in the case of transferrin saturation, which may contribute to iron misregulation, pro-oxidative stress and anti-oxidative imbalance in the human body. Under aerobic conditions, oxidative stress is a common phenomenon in many biological systems. Human semen has its own molecular mechanisms for protection against the free radicals created by immune reactions or normal respiratory processes, and the creation and scavenging of free radicals is maintained in equilibrium during spermatogenesis. Prooxidative or anti-oxidative imbalances in the semen are associated with male infertility. ${ }^{21}$ Lucesoli et al. ${ }^{22,23}$ reported that iron accumulation associated with either acute or chronic iron overload led to a subtle iron increase in the testes and that this increase was associated with oxidative damage to proteins, lipids, and DNA. The extent of oxidative damage and the decrease in spermatogenesis were dependent on the dose of iron and on its accumulation in the testes. ${ }^{14}$ Oxidation could modify sperm function, which might cause male reproductive system dysfunction, increased teratogenicity incidence and cancer in the progeny.

Several studies have attempted to investigate the possibility that HFE mutations induce dysfunction of spermatogenesis and/or the hypothalamic-pituitary-gonadal axis (Table 3). Peterlin et al. ${ }^{24}$ did not find any relationship between the $\mathrm{C} 282 \mathrm{Y}$ and $\mathrm{H} 63 \mathrm{D}$ mutations in the HFE gene and the clinical characteristics of infertile men (sperm concentration, rapid progressive sperm motility, normal morphology, testicular volume and FSH levels) in the Slovenian population. They suggested that the lack of an association between the C282Y and H63D mutations and male infertility could be either because the two mutations may each confer a low relative risk or because the increase of iron serum levels associated with these two mutations is not sufficient to impair human spermatogenesis. Gunel-Ozcan et al. ${ }^{25}$ indicated that the overall mean FSH levels were higher, whereas sperm motility was lower in infertile men with the HFE H63D mutation compared with subjects lacking this mutation in the Turkish population. In addition, a comparison of the allele frequencies for the HFE H63D mutation in infertile men with abnormal sperm motility versus in infertile men

Table 6 Main results for the H63D and C282Y mutations in the meta-analysis

\begin{tabular}{lcccc}
\hline Variables & Cases/controls & H63D/H63D $+H 63 D / w t v s ~ w t / w t$ & & C282Y/C282Y+C282Y/wt vs wt/wt \\
\cline { 3 - 3 } & $833 / 811$ & OR (95\% Cl) & $P$ & OR (95\% Cl) \\
\hline Ethnicity & & & \\
Caucasian & $389 / 388$ & $0.94(0.71-1.25)$ & 0.674 & $1.11(0.61-2.01)$ \\
Asian & $444 / 423$ & & 0.375 \\
\hline
\end{tabular}


with normal sperm motility revealed a large difference $(P=0.005)$. Thus, the HFE H63D heterozygosity mutation appears to be an important risk factor for impaired sperm motility and may contribute to the development of male infertility. Meeker et al. ${ }^{26}$ demonstrated an inverse relationship between human sperm parameters and serum hormone levels, including FSH. Buretić-Tomljanović et al. ${ }^{17}$ studied the impact of HFE mutations and transferrin genotypes on gonadotropin serum levels. Their study revealed that the sperm count and progressive sperm motility did not correlate with the HFE or TF genotype or their combination. In contrast, a statistically significant correlation was observed between serum FSH and LH levels and the combined HFE H63D/TFC2 genotype in 97 men with idiopathic infertility in the Croatian population. Therefore, the HFE and TF genes together may influence hypothalamic-pituitary-gonadal axis function at the level of the pituitary or testes. In the present study, our data agree with previous findings ${ }^{10}$ demonstrating that the H63D, S65C and C282Y mutations in the HFE gene are rare in the Chinese Han population. No C282Y or S65C mutations were detected, and there was no evident difference in the $\mathrm{H} 63 \mathrm{D}$ heterozygote frequencies between the groups of infertile and fertile men, which were 5.2\% (23/ $444)$ and $6.4 \%(27 / 423)$, respectively $(P=0.448)$. For men with azoospermia, oligozoospermia or asthenospermia, the H63D heterozygote frequencies were not significantly different from those in the fertile controls. The H63D genotype distributions in both the case and control groups were compatible with Hardy-Weinberg expectations. Furthermore, we did not identify a relationship between H63D heterozygosity and any clinical characteristic (sperm concentration, rapid progressive sperm motility, LH, FSH and T levels) associated with idiopathic male infertility in the Chinese Han population. The HFE genotype frequency in infertile and control men from published studies (Table 3) showed that the HFE C282Y mutation was rare in both populations. In our study, we found no homozygotes, but we identified 5.2\% heterozygotes for the H63D mutation among the infertile males. When compared with European populations, H63D heterozygotes are rare in the Chinese Han population. Different ethnic and genetic backgrounds could be associated with relatively uncommon iron overload and male infertility in the population studies. To derive a more precise estimation of the association between the HFE mutations and the risk of male infertility, we performed a meta-analysis. A comprehensive search was conducted to identify all case-control studies of HFE mutations and male infertility risk. We used ORs with 95\% CIs to assess the strength of the association. Overall, we found that both H63D and C282Y mutations were not significantly associated with male infertility risk (Table 6 and Figures 1 and 2). To further investigate the relevance of HFE mutations to the pathogenesis of male infertility, a large-scale population screen is necessary.

\section{AUTHOR CONTRIBUTIONS}

XYY participated in the design of the study, performed the experiment and drafted the manuscript. BBW conceived and designed the experiments and analysed the data. ZCX revised the manuscript critically for important intellectual content and helped to resolve some difficulties during the experiments. TL carried out the molecular genetic studies and helped to draft the manuscript. JJ, XF, LHY and KM collected all the samples. YFP and XM conceived and designed the experiments. All the authors have read and approved the manuscript being submitted.

\section{COMPETING FINANCIAL INTERESTS}

The authors have declared that no competing interests exist.

\section{ACKNOWLEDGMENTS}

We are grateful to the staff and volunteer participants for their close cooperation and significant contributions. We thank Mr Lian-Ping He (Department of Preventive Medicine, Wannan Medical College) for the statistical analysis. This work was supported by National Basic Research Program of China (No. 2010CB945102), National Natural Science Foundation of China (No. 30973197), National Science \& Technology Pillar Program of China (No. 2008BAH24B05) and National Infrastructure Program of Chinese Genetic Resources (No. 2006DKA21300).

1 Hong $\mathrm{K}, \mathrm{Xu} \mathrm{QQ}$, Zhao YP, Gu YQ, Jiang $\mathrm{H}$ et al. Andrology in China: current status and 10 years' progress. Asian J Androl 2011; 13: 512-8.

2 Hann MC, Lau PE, Tempest HG. Meiotic recombination and male infertility: from basic science to clinical reality? Asian J Androl 2011; 13: 212-8.

3 Giuliani R, Antonucci I, Torrente I, Grammatico P, Palka G et al. Identification of the second CFTR mutation in patients with congenital bilateral absence of vas deferens undergoing ART protocols. Asian J Androl 2010; 12: 819-26.

4 Liu G, Shi QW, Lu GX. A newly discovered mutation in PICK1 in a human with globozoospermia. Asian J Androl 2010; 12: 556-60.

5 Waheed A, Parkkila S, Zhou XY, Tomatsu S, Tsuchihashi Z et al. Hereditary hemochromatosis: effects of $\mathrm{C} 282 \mathrm{Y}$ and $\mathrm{H} 63 \mathrm{D}$ mutations on association with beta2-microglobulin, intracellular processing, and cell surface expression of the HFE protein in COS-7 cells. Proc Natl Acad Sci USA 1997; 94: 12384-9.

6 Gross CN, Irrinki A, Feder JN, Enns CA. Co-trafficking of HFE, a nonclassical major histocompatibility complex class I protein, with the transferrin receptor implies a role in intracellular iron regulation. J Biol Chem 1998; 273: 22068-74.

7 Simon M, Bourel M, Fauchet R, Genetet B. Association of HLA-A3 and HLA-B14 antigens with idiopathic haemochromatosis. Gut 1976; 17: 332-4.

8 Feder JN, Gnirke A, Thomas W, Tsuchihashi Z, Ruddy DA et al. A novel MHC class Ilike gene is mutated in patients with hereditary haemochromatosis. Nat Genet 1996; 13: 399-408.

9 Spínola C, Brehm A, Spínola H. Prevalence of H63D, S65C, and C282Y hereditary hemochromatosis gene variants in Madeira Island (Portugal). Ann Hematol 2011; 90: 29-32.

10 Lin A, Yan WH, Xu HH, Zhu M, Zhou MY. Analysis of the HFE gene (C282Y, H63D and S65C) mutations in a general Chinese Han population. Tissue Antigens 2007; 70: 252-5.

11 Merryweather-Clarke AT, Pointon JJ, Shearman JD, Robson KJ. Global prevalence of putative haemochromatosis mutations. J Med Genet 1997; 34: 275-8.

12 Feder JN, Tsuchihashi Z, Irrinki A, Lee VK, Mapa FA et al. The hemochromatosis founder mutation in HLA-H disrupts beta2-microglobulin interaction and cell surface expression. J Biol Chem 1997; 272: 14025-8.

13 Fleming RE, Sly WS. Mechanisms of iron accumulation in hereditary hemochromatosis. Annu Rev Physiol 2002; 64: 663-80.

14 Lucesoli F, Caligiuri M, Roberti MF, Perazzo JC, Fraga CG. Dose-dependent increase of oxidative damage in the testes of rats subjected to acute iron overload. Arch Biochem Biophys 1999; 372: 37-43.

15 Merker HJ, Vormann J, Günther T. Iron-induced injury of rat testis. Andrologia 1996; 28: 267-73.

16 Kelly TM, Edwards CQ, Meikle AW, Kushner JP. Hypogonadism in hemochromatosis: reversal with iron depletion. Ann Intern Med 1984; 101: 629-32.

17 Buretić-Tomljanović A, Vlastelić I, Radojcić Badovinac A, Starcević-Cizmarević N, Nadalin $\mathrm{S}$ et al. The impact of hemochromatosis mutations and transferrin genotype on gonadotropin serum levels in infertile men. Fertil Steril 2009; 91. 1793-800.

18 Migrenne S, Racine C, Guillou F, Habert R. Pituitary hormones inhibit the function and differentiation of fetal Sertoli cells. Endocrinology 2003; 144: 2617-22.

19 Pryor JL, Krieg RJ Jr, Evans WS, Batson J, Turner TT. Luteinizing hormone secretion by male rat pituitary cells perifused in vitro: effect of experimental left varicocele and orchiectomy. J Androl 1989; 10: 372-7.

20 Zhou XY, Tomatsu S, Fleming RE, Parkkila S, Waheed A et al. HFE gene knockout produces mouse model of hereditary hemochromatosis. Proc Natl Acad Sci USA 1998; 95: 2492-7.

21 Garrido N, Meseguer M, Simon C, Pellicer A, Remohi J. Pro-oxidative and antioxidative imbalance in human semen and its relation with male fertility. Asian $J$ Androl 2004; 6: 59-65.

22 Lucesoli F, Fraga CG. Oxidative damage to lipids and DNA concurrent with decrease of antioxidants in rat testes after acute iron intoxication. Arch Biochem Biophys 1995; 316: $567-71$

23 Lucesoli F, Fraga CG. Oxidative stress in testes of rats subjected to chronic iron intoxication and al pha-tocopherol supplementation. Toxicology 1999; 132: 179-86.

24 Peterlin B, Kunej T, Hruskovicová H, Ferk P, Gersak K et al. Analysis of the hemochromatosis mutations C282Y and H63D in infertile men. Fertil Steril 2006; 86: 1796-8.

25 Gunel-Ozcan A, Basar MM, Kisa U, Ankarali HC. Hereditary haemochromatosis gene (HFE) H63D mutation shows an association with abnormal sperm motility. Mol Biol Rep 2009; 36: 1709-14.

26 Meeker JD, Godfrey-Bailey L, Hauser R. Relationships between serum hormone levels and semen quality among men from an infertility clinic. J Andro/ 2007; 28: 397-406. 